\title{
Lead isotope ratios in ambient aerosols from Taipei, Taiwan: Identifying long-range transport of airborne $\mathrm{Pb}$ from the Yangtze Delta
}

\author{
Shih-Chieh $\mathrm{Hsu}^{\mathrm{a}, *}$, Shaw Chen Liu ${ }^{\mathrm{a}}$, Woei-Lih Jeng ${ }^{\mathrm{b}}$, Charles C. K. Chou ${ }^{\mathrm{a}}$, \\ Ru-Ting Hsu ${ }^{\mathrm{a}}$, Yi-Tang Huang ${ }^{\mathrm{a}}$, Yun-Wen Chen ${ }^{\mathrm{a}}$ \\ ${ }^{a}$ Research Center for Environmental Changes, Academia Sinica, Taipei, Taiwan, ROC \\ ' Institute of Oceanography, National Taiwan University, Taipei, Taiwan, ROC
}

Received 20 October 2005; accepted 21 April 2006

\begin{abstract}
A total of 142 sets of $\mathrm{PM}_{10}$ and $\mathrm{PM}_{2.5}$ aerosol particles collected from Taipei during a period from April 2003 to February 2004 were determined for atmospheric $\mathrm{Pb}$ concentrations. Among these samples, 77 sets of samples representing four seasons were selected for measuring $\mathrm{Pb}$ isotopic compositions to determine the relative contributions of various pollution sources. Results reveal an evident seasonality of high winter and low summer $\mathrm{Pb}$ concentrations, resembling those observed in Shanghai, China as well as many East Asian countries. Together with synoptic atmospheric conditions analysis, the seasonal pattern is attributable to the impact of long-range transport of $\mathrm{Pb}$-rich anthropogenic aerosols from the Chinese pollution outflows in the northeast monsoon and to the effective removal by wet deposition in summer. Results of ${ }^{206} \mathrm{~Pb} /{ }^{207} \mathrm{~Pb}$ and ${ }^{208} \mathrm{~Pb} /{ }^{207} \mathrm{~Pb}$ isotope ratios show a minimum in summer, thereafter increasing progressively to fall to winter and reaching a maximum in spring. The summer values are similar to that of tunnel particles for ${ }^{206} \mathrm{~Pb} /{ }^{207} \mathrm{~Pb}$ ratio but dissimilar to that of tunnel particles for ${ }^{208} \mathrm{~Pb} /{ }^{207} \mathrm{~Pb}$ ratio. Here summer aerosols may represent a local pollutioninfluenced case, and tunnel particles represent a vehicle exhaust source for atmospheric $\mathrm{Pb}$. Therefore apart from vehicle emissions of $\mathrm{Pb}$ for Taipei aerosols, other sources such as incineration, metalliferous industry and coal combustion of fire power plants need to be taken into account. The winter and spring $\mathrm{Pb}$ isotope ratios are quite comparable with those measured in China, especially Shanghai in the Yangtze Delta. Again this demonstrates northern Taiwan has already been affected by continental pollution of long-range transport during the northeast monsoon season beginning in early fall and ending in late spring. By employing a two end-member mixing model based on the assumption that the summer case represents the local source end-member, the relative contributions of long-range transport for anthropogenic $\mathrm{Pb}$ have been estimated to be $40 \%$ in fall, $50 \%$ in winter, and $75-85 \%$ in spring.
\end{abstract}

(C) 2006 Elsevier Ltd. All rights reserved.

Keywords: Lead isotope composition; Source apportionment; Asian pollution outflow; Cross-boundary transport; Shanghai

\footnotetext{
*Corresponding author. Tel.: + 886226539885 ext 252; fax: +886227833584 .

E-mail address: schsu815@rcec.sinica.edu.tw (S.-C. Hsu).
}

\section{Introduction}

Lead has adverse health effects, especially with respect to the damage to the nervous systems of 
fetuses and young children, resulting in lowered IQ and learning problems. Usually, one of the major sources of $\mathrm{Pb}$ exposure is air pollution. Lead air pollution abruptly became severe until leaded gasoline was used since 1920s (Nriagu, 1996), of which the principal lead compound of leaded gasoline is tetraethyl lead $\left(\mathrm{Pb}\left(\mathrm{C}_{2} \mathrm{H}_{5}\right)_{4}\right)$. As a result of utilization of leaded gasoline together with other various emission sources like mining, smelting, waste incineration and coal combustion, atmospheric $\mathrm{Pb}$ was fast, greatly built up. It is not only harmful to public health but also to the biota in both terrestrial and aquatic ecosystems. Through long-range transport airborne $\mathrm{Pb}$ has also enhanced the $\mathrm{Pb}$ concentrations globally in surface oceans and other aquatic environments and altered the biogeochemical cycle of $\mathrm{Pb}$ in these environmental systems (Patterson and Settle, 1987). This has been well demonstrated by high time-resolution $\mathrm{Pb}$ analysis of a variety of environmental archives such as marine sediments (Marcantonio et al., 2002), lake sediments (Renberg et al., 1994), coal (Shen and Boyle, 1987), ice cores (Planchon et al., 2003), peat bog (Shotyk et al., 1998) and moss (Rosman et al., 1998). A lot of efforts have been made for reducing $\mathrm{Pb}$ in air. Fortunately, the gradual introduction of unleaded gasoline has greatly reduced atmospheric $\mathrm{Pb}$ concentrations generally to a value much lower than $100 \mathrm{ng} \mathrm{m}^{-3}$ in most of developed countries since 1970s (Nriagu, 1989; Var et al., 2000).

Unleaded gasoline was officially introduced in Taiwan in 1993. In 2000, the lead content in gasoline has been reduced even to a low level of $0.026 \mathrm{gl}^{-1}$. As a consequence, atmospheric $\mathrm{Pb}$ in Taipei has already sharply declined from higher than $500 \mathrm{ng} \mathrm{m}^{-3}$ in 1991 (Mao and Chen, 1996) to the present level with an annual mean of $34 \mathrm{ng} \mathrm{m}^{-3}$ in 2002 (Hsu et al., 2005). Nevertheless, Hsu et al. (2005) observed a maximal concentration in winter $\left(62 \mathrm{ng} \mathrm{m}^{-3}\right)$ when the northeast monsoon wind prevails higher than those in the rest of seasons by a factor of one to two, attributable to the long-range transport of Chinese pollution outflows. This seasonal pattern is comparably consistent with that measured in Shanghai based on a 10-year long-term database (Chen et al., 2005). In Shanghai, at present extraordinarily high $\mathrm{Pb}$ concentrations with a mean value of $500 \mathrm{ng} \mathrm{m}^{-3}$ are still occurring in winter although leaded gasoline was banned in Beijing and Shanghai during 1997 and extended to the entire nation in 2000 (Zheng et al., 2004). The major pollution source of airborne $\mathrm{Pb}$ was suggested to be from coal combustion rather than from vehicle emission that accounted for less than $30 \%$ of the total airborne $\mathrm{Pb}$ loadings in Shanghai according to $\mathrm{Pb}$ isotopic compositions (Zheng et al., 2004; Chen et al., 2005). It was also verified that airborne $\mathrm{Pb}$ of Chinese pollution outflows can be carried toward other East Asian countries and areas through longrange transport (Mukai et al., 1994; Fang et al., 1999; Kim and Song, 1997; Var et al., 2000; Hsu et al., 2005). Moreover, heavy $\mathrm{Pb}$ air pollution in China has resulted in high $\mathrm{Pb}$ concentration in its neighboring East China Sea with the highest $\mathrm{Pb}$ in seawater among the world oceans (Lin et al., 2000).

In order to qualitatively and quantitatively characterize the temporal variation and assess the relative contribution of atmospheric $\mathrm{Pb}$ from longrange transport in northern Taiwan more efforts are merited, that will make air quality managements more feasible and practical. Nonetheless, atmospheric $\mathrm{Pb}$ concentration alone cannot be used to achieve these goals because the mixing process of multiple components and preferential removal of specific $\mathrm{Pb}$-associated particles during transport will become more difficult in identifying the likely sources. A specific fingerprint for $\mathrm{Pb}$-like isotopic compositions may be effective for source apportionments (Sturges and Barrie, 1987; Mukai et al., 1994; Monna et al., 1997; Flament et al., 2002). Isotopic compositions of these human-made $\mathrm{Pb}$ sources are related to the isotope geochemistry of ore deposits. Temporal and geographic variability in the isotopic compositions of $\mathrm{Pb}$ can provide more convincing evidence for source apportionment as different anthropogenic $\mathrm{Pb}$ sources often exhibit their own characteristic $\mathrm{Pb}$ isotope ratios (Mukai et al., 1994; Bollhofer and Rosman, 2001). Lead isotope ratios can thus be a reliable tool for identifying anthropogenic $\mathrm{Pb}$ sources (source regions). Moreover, this technique has been extensively applied in various environmental samples since $\mathrm{Pb}$ isotope ratio measurements were feasible by using ICP-MS (Becker and Dietze, 2000).

Like a fingerprint or gene, the ratios of $\mathrm{Pb}$ isotopes are useful for tracing sources of pollution and the movement of air masses (Bollhofer and Rosman, 2001). Based upon the characterizations of $\mathrm{Pb}$ isotope ratios of airborne particulate samples collected from Oki Island located in the Sea of Japan, Mukai et al. (1994) identified the Pb source of long-range transport from China, Russia, South Korea and Japan. Bollhofer and Rosman (2001) recently carried out a global measurement for 
atmospheric $\mathrm{Pb}$ isotope ratios. Geographic variations in $\mathrm{Pb}$ isotope ratios of aerosols have been demonstrated by a ${ }^{208} \mathrm{~Pb} /{ }^{207} \mathrm{~Pb}$ versus ${ }^{206} \mathrm{~Pb} /{ }^{207} \mathrm{~Pb}$ plot. By using the isotopic data, long-range transport of $\mathrm{Pb}$ pollution from China and Russia has been detected in the western United States and parts of Europe.

It will be expected that considerable quantities of air pollutants will continuously be delivered toward the downwind countries and regions as the Chinese mainland is in rapid developments of industrialization and urbanization. In order to precisely assess the impact of long-range transport of Asian continental pollution outflows on local air quality, long-term measurements with respect to seasonality and annual (even interannual and decadal) variations as well as the applications of effective techniques are urgently required. Ambient aerosol samples $\left(\mathrm{PM}_{10}\right.$ and $\left.\mathrm{PM}_{2.5}\right)$ collected in metropolitan Taipei from early 2003 to early 2004 were determined for $\mathrm{Pb}$ concentrations and $\mathrm{Pb}$ isotopic compositions. Coupled with our previous study, a 2-year seasonality was established in the study. Based on the results of $\mathrm{Pb}$ isotope ratios together with air-mass trajectory analysis, the relative contributions of long-range transport of airborne $\mathrm{Pb}$ were computed using a two-endmember mixing model. This study is the first systematic investigation on the isotopic compositions of atmospheric $\mathrm{Pb}$ in Taiwan.

\section{Materials and methods}

\subsection{Sampling}

A total of 142 sets of $\mathrm{PM}_{10}$ and $\mathrm{PM}_{2.5}$ aerosol samples were collected from metropolitan Taipei in the time period from April 2003 to February 2004 and determined for $\mathrm{Pb}$ concentrations. A total of 77 sets of $\mathrm{PM}_{10}$ and $\mathrm{PM}_{2.5}$ aerosol samples (52 sets collected during the period from April 2003 to February 2004 and another 25 sets collected in March 2003) were determined for $\mathrm{Pb}$ isotopes. Details of sampling time for the samples used for analyzing $\mathrm{Pb}$ isotope ratios are given in Table 1. The sampling site was located at the Central Weather Bureau (CWB) in metropolitan Taipei, Taiwan. The Partisol $^{\circledR}$ Model 2300 speciation sampler (Rupprecht \& Patashnick Co. Inc., Albany, NY, USA) was employed to simultaneously collect $\mathrm{PM}_{10}$ and $\mathrm{PM}_{2.5}$ ambient aerosol particles. An active volumetric flow control system was used to maintain the
Table 1

Collection periods and sample numbers (in unit of set) of aerosol samples $\left(\mathrm{PM}_{10}\right.$ and $\left.\mathrm{PM}_{2.5}\right)$ collected from Taipei, Taiwan during four seasons for $\mathrm{Pb}$ isotopic analysis

\begin{tabular}{lll}
\hline $\begin{array}{l}\text { Sample } \\
\text { category }\end{array}$ & Collection period & $\begin{array}{l}\text { Sample } \\
\text { number }\end{array}$ \\
\hline Spring & $\begin{array}{l}\text { 3/7-3/14/2003 (excluding 0307D, } \\
\text { 0310D and 0314N) }\end{array}$ & 25 \\
& $3 / 25-3 / 31 / 2003$ (excluding 0328N \\
& and 0331D) & \\
Summer & $7 / 28-8 / 3 / 2003$ & 14 \\
Fall & $11 / 24 /-11 / 30 / 2003$ & 10 \\
Winter & $2 / 6-2 / 19 / 2004$ & 28 \\
\hline
\end{tabular}

Samples are identified by a sampling time code in the month $(\mathrm{mm})$, day $(\mathrm{dd})$, and daytime/nighttime $(\mathrm{D} / \mathrm{N})$ format; e.g., 0307D denotes March 7 daytime.

volumetric flow rate at a constant rate of $16.71 \mathrm{~min}^{-1}$. The samplers were set on the rooftop of the CWB building approximately $25 \mathrm{~m}$ above the ground level. The medium used for aerosol filtration was polytetrafluoroethylene (PTFE) membrane filters (PallGelman, $1.0 \mu \mathrm{m}$ pore size and $47 \mathrm{~mm}$ in diameter with a PE ring). Sampling was carried out in the last week of each month; besides, additional sampling was made when dust events were forecasted by the Environmental Protection Administration (EPA) of Taiwan. Samples were collected at 12-h intervals. Details relevant to the sampling information and strategy can be found elsewhere (Hsu et al., 2004, 2005). Although unleaded gasoline has been completely available, unleaded gasoline still contains low levels of $\mathrm{Pb}$; the lead content in gasoline is approximately $0.026 \mathrm{gl}^{-1}$. To evaluate the contribution of vehicle emissions, four tunnel particle samples were collected from the tiling wall of three main tunnels (Xin-Hai, Zi-Qiang and Ba-Du) in Taipei.

\subsection{Chemical analysis}

Aerosol-laden PTFE filters were completely dissolved in an acid mixture, i.e. $5 \mathrm{ml} \mathrm{HNO}_{3}, 5 \mathrm{ml} \mathrm{HF}$,

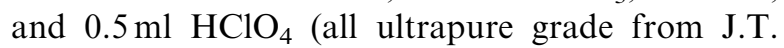
Baker) in Teflon beakers. The digestion solution was diluted with Milli-Q water to $20 \mathrm{ml}$ (in $2 \%$ $\mathrm{HNO}_{3}$ ). The acid digestion was also used for tunnel particle samples. Lead concentrations were determined using a quadrupole-based inductively coupled plasma mass spectrophotometer (ICP-MS, Elan 6100, Perkin Elmer ${ }^{\mathrm{TM}}$ SCIEX, USA). Indium was added to the digests as an internal standard 
$\left(10 \mu \mathrm{gl}^{-1}\right)$. The detection limit for $\mathrm{Pb}$ was $0.2 \mathrm{ng} \mathrm{m}^{-3}$. Calibration was achieved using a multi-element standard prepared from stock standard (Merck) made up in a $2 \% \mathrm{HNO}_{3}$ solution. The quality assurance and quality control (QA/QC) of analyses were validated by analyzing the standard reference material (NIST SRM 1648, urban particulate matter from National Institute of Standards and Technology, USA). The recovered value for the target element fell within $3 \%$ of certified values $(n=5)$. Blanks were used to assess reagents, methods, standards, instruments, and calibrations. The details on the digestion method and ICP-MS analysis have been described elsewhere (Hsu et al., 2004, 2005).

In the recent decade, various aspects of studies on lead isotope ratios in geological, environmental and biological samples utilizing the quadrupole-based ICP-MS have been well documented (Becker and Dietze, 2000, and references therein). Those studies have verified the instrumentation having sufficient precision and accuracy of meeting the research requirements. Lead isotopic determinations were performed by the quadrupole-based ICP-MS; this analysis run was separated from the concentration measurement. The intensities of ${ }^{206} \mathrm{~Pb},{ }^{207} \mathrm{~Pb}$, and ${ }^{208} \mathrm{~Pb}$ were measured in the peak hop mode with short settling times, $100 \mathrm{~ms}$ dwell times, and total measurement times of $75 \mathrm{~s}$. The relative standard deviation (RSD) in the measurements of $\mathrm{Pb}$ isotope ratios $\left({ }^{207} \mathrm{~Pb} /{ }^{206} \mathrm{~Pb}\right.$ and $\left.{ }^{208} \mathrm{~Pb} /{ }^{206} \mathrm{~Pb}\right)$ at the $5 \mu \mathrm{g} 1^{-1}$ level was about $0.5 \%$. An isotopic standard reference material, NIST SRM 981 (common lead isotope) was analyzed at a regular interval of $n=5$ in each batch for data quality control, i.e., calibration and monitoring the instrument drift and mass bias. The ratio correction factors obtained were typically in the range $0.995-1.005$ for both ratios. Modest improvements to the precision can be achieved by increasing analysis time if necessary. The optimization of the quadrupole-based ICP-MS instruments, the nature of noise sources, and strategies to enhance precision and accuracy have been dealt with by a number of authors (Monna et al., 2000).

\section{Results and discussion}

\subsection{Concentrations of airborne Pb and its temporal variations}

Atmospheric concentrations of particulate $\mathrm{Pb}$ measured in ambient $\mathrm{PM}_{10}$ and $\mathrm{PM}_{2.5}$ aerosols in Taipei from April 2003 to February 2004 range

Table 2

Data summary for atmospheric $\mathrm{Pb}$ concentrations in Taipei $\mathrm{PM}_{10}$ aerosols during a period from April 2003 to February 2004

\begin{tabular}{|c|c|c|c|c|}
\hline & Range (Mean $\pm 1 \sigma$ ) & Collection period & Sample type & $\begin{array}{l}\text { Sample } \\
\text { number }\end{array}$ \\
\hline Taipei, Taiwan ${ }^{\mathrm{b}}$ & $N^{a}-404(27 \pm 61)$ & $\begin{array}{l}\text { April 2003-February } 2004 \\
\text { (nearly a year) }\end{array}$ & $\mathrm{PM}_{10}$ & 142 \\
\hline Taipei, Taiwan ${ }^{c}$ & ND-207 (34) & $\begin{array}{l}\text { March 2002-March } 2003 \text { (over a } \\
\text { year) }\end{array}$ & $\mathrm{PM}_{10}$ & 186 \\
\hline Hong Kong, China ${ }^{\mathrm{d}}$ & $\sim 85$ & $\begin{array}{l}\text { November 2000-February } \\
\text { (Winter) }\end{array}$ & $\mathrm{PM}_{10}$ & - \\
\hline Shanghai, China ${ }^{\mathrm{e}}$ & $167-854(515)$ & Late 2001-Early 2002 (Winter) & $\mathrm{PM}_{10}$ & - \\
\hline \multirow[t]{2}{*}{ Beijing, China $^{\mathrm{f}}$} & $\sim 150^{\mathrm{g}}$ & June -July 2002 (Summer) & $\mathrm{PM}_{10}$ & 65 \\
\hline & $\sim 440^{\mathrm{g}}$ & December 2002 (Winter) & $\mathrm{PM}_{10}$ & 56 \\
\hline Tokyo, Japan $^{\text {h }}$ & $(64.4)$ & 1995-2000 (Five years) & $\mathrm{PM}_{11}$ & - \\
\hline Seoul, Korea ${ }^{\mathrm{i}}$ & $39-401(200 \pm 97)$ & December 2002 & $\mathrm{PM}_{10}$ & 17 \\
\hline
\end{tabular}

For comparison, other results measured in several selected East Asian countries and areas are also given.

${ }^{\mathrm{a}}$ Below the detection limit $\left(0.2 \mathrm{ng} \mathrm{m}^{-3}\right)$.

${ }^{\mathrm{b}}$ This work.

${ }^{\mathrm{c}}$ Our previous study, refer to Hsu et al. (2005).

${ }^{\mathrm{d}}$ Ho et al. (2003).

${ }^{\mathrm{e}}$ Zheng et al. (2004).

${ }^{\mathrm{f}}$ Sun et al. (2004).

${ }^{\mathrm{g}}$ Calculated from the published data in the cited references.

${ }^{\mathrm{h}}$ Zheng et al. (2004) and references therein.

${ }^{\mathrm{i}}$ Mishra et al. (2004). 
from under detection limit $\left(<0.2 \mathrm{ng} \mathrm{m}^{-3}\right)$ to $404 \mathrm{ng} \mathrm{m}^{-3}$ with a geometric mean of $27 \mathrm{ng} \mathrm{m}^{-3}$, as summarized in Table 2. The arithmetic mean and median were also calculated to be 50 and $29 \mathrm{ng} \mathrm{m}^{-3}$, respectively. The two values of the geometric mean and the median are close, reflecting that the data set of $\mathrm{Pb}$ is a log-normal distribution. The values of $\mathrm{Pb}$ concentrations are very consistent with our previous results conducted at the same site in Taipei from March 2002 to March 2003 (Hsu et al., 2005). For comparison, data on atmospheric $\mathrm{Pb}$ concentrations from the East Asian mega-cities were compiled in Table 2. From the viewpoint of public health, the $\mathrm{Pb}$ concentrations are at low levels following the standard guideline of exposure risk except few days. Compared to those data obtained from Taipei about 10 years ago (Mao and Chen, 1996), airborne $\mathrm{Pb}$ concentrations have declined greatly from an annual mean of higher than $100 \mathrm{ng} \mathrm{m}^{-3}$ to the present level of around $30 \mathrm{ng} \mathrm{m}^{-3}$ owing to the gradual phase-out of leaded gasoline over Taiwan since 1993. Compiling the present data with our previous data, a 2-year seasonality (i.e., 2002 and 2003) can be established, as illustrated in Fig. 1. Obviously, the seasonality of airborne $\mathrm{Pb}$ in 2002 is similar to that in 2003, commonly showing a winter maximum and a spring/summer minimum. This temporal pattern is very similar to that observed in Shanghai (Chen et al., 2005) as well as other Chinese coastal cities (Zhang and Friedlander, 2000; Dan et al., 2004). Also, it resembles those observed in the surrounding countries and areas such as Korea (Kim and Song, 1997), Japan (Var et al., 2000) and Hong Kong (Ho et al., 2003).

Based on the synoptic atmospheric conditions together with the air-mass back trajectory analysis, numerous studies have documented that during the northeastern monsoon seasons massive quantities of air pollutants are carried to northern Taiwan (Hsu et al., 2004, 2005; Lin et al., 2005). Wang (2005) made a 9-year (1994-2002) long-term air-mass back trajectory analysis, definitely demonstrating that the air parcel usually passes over the Changjiang Delta (or Shanghai City) where is now the most urbanized and industrialized area in mainland China (Hsu et al., 2004). For example, two cases happened on 29 November 2003 and 6 February 2004 when atmospheric $\mathrm{Pb}$ concentrations reached 276 and $132 \mathrm{ng} \mathrm{m}^{-3}$, respectively. By using not only backward but also forward air mass trajectory analysis (Fig. 2), it is clear that air masses can quickly move from Shanghai (or Yangtze Delta) to northern
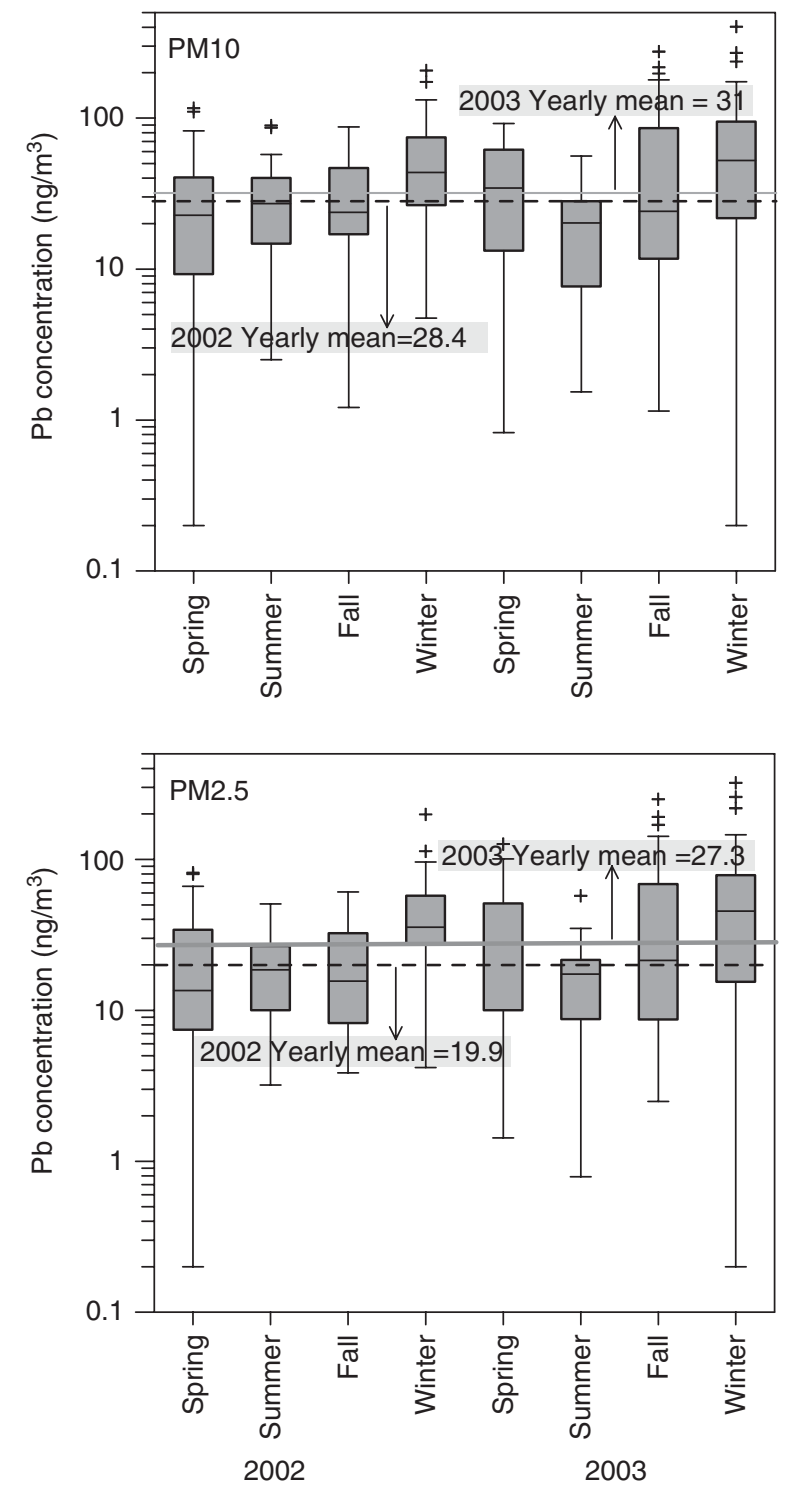

Fig. 1. Seasonal variations in atmospheric $\mathrm{Pb}$ concentrations in Taipei ambient $\mathbf{P M}_{10}$ (upper panel) and $\mathbf{P M}_{2.5}$ (lower panel) aerosols during a 2-year period from March 2002 to February 2004, of which data for the first year were taken from our previous study (Hsu et al., 2005).

Taiwan approximately in 1 day. The air parcels are capable of bringing a large amount of $\mathrm{Pb}$-bound anthropogenic aerosols to northern Taiwan. Chen et al. (2005) found a permanent winter maximum for airborne $\mathrm{Pb}$ in the recent decade, and the present wintertime concentrations are still up to $500 \mathrm{ng} \mathrm{m}^{-3}$, reflecting that $\mathrm{Pb}$ air pollution is continuously severe. Therefore, along with seasonal differences in emission strength the seasonality can be attributable to two other causes: cross-boundary transport 
NOAA HYSPLIT MODEL

Backward trajectories ending at 12 UTC 29 Nov 03 FNL Meteorological Data

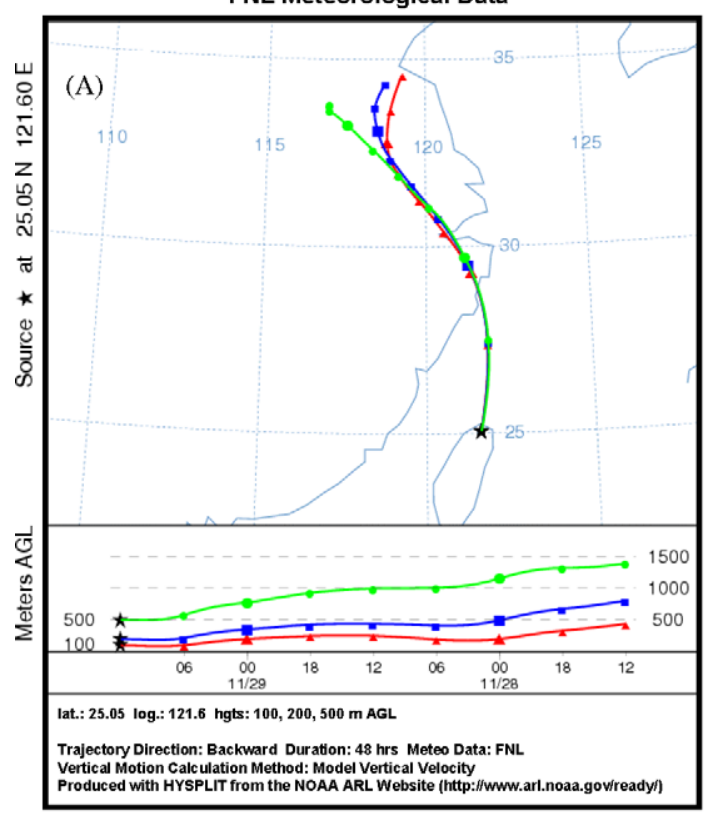

NOAA HYSPLIT MODEL

Backward trajectories ending at 04 UTC 06 Feb 04 FNL Meteorological Data

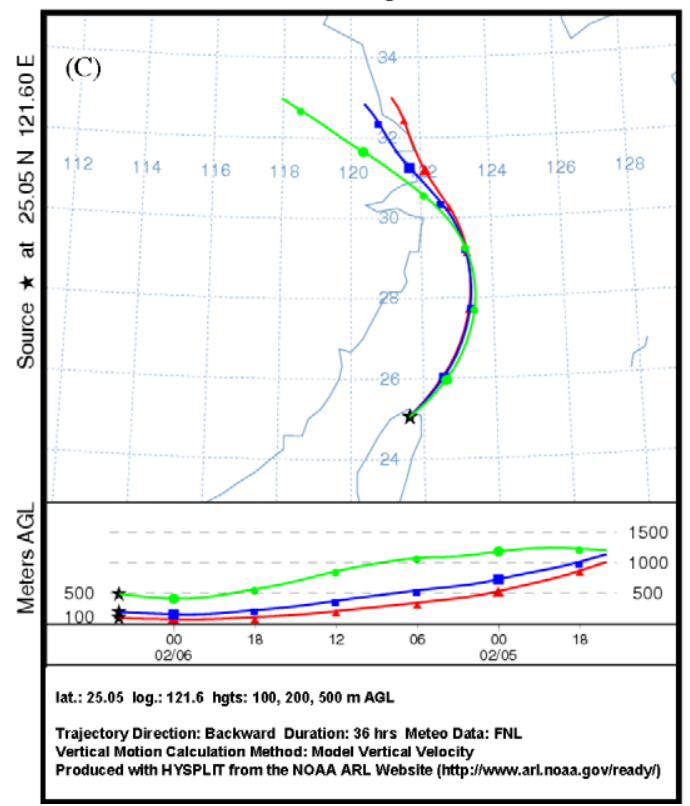

NOAA HYSPLIT MODEL

Forward trajectories starting at 18 UTC 28 Nov 03 FNL Meteorological Data

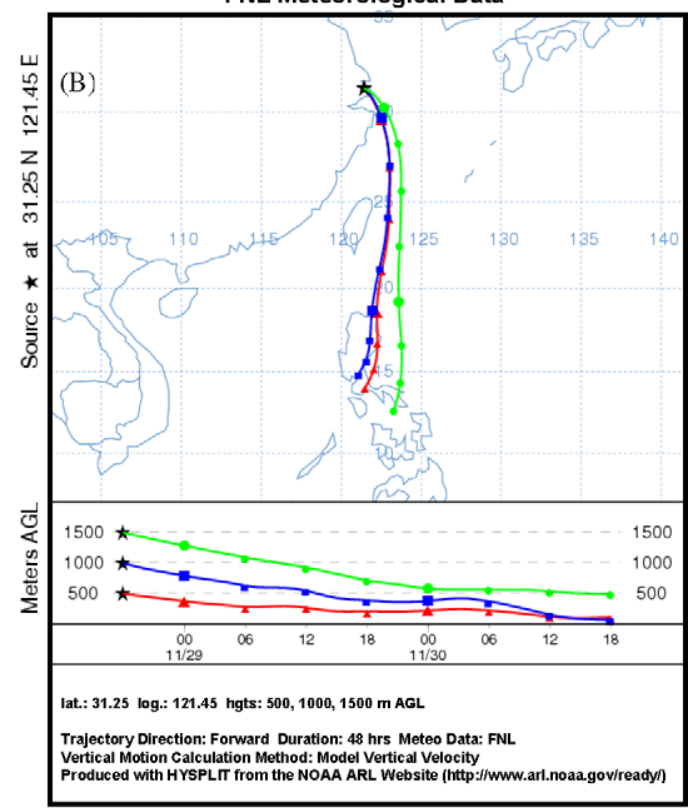

NOAA HYSPLIT MODEL Backward trajectories ending at 00 UTC 05 Feb 04 FNL Meteorological Data

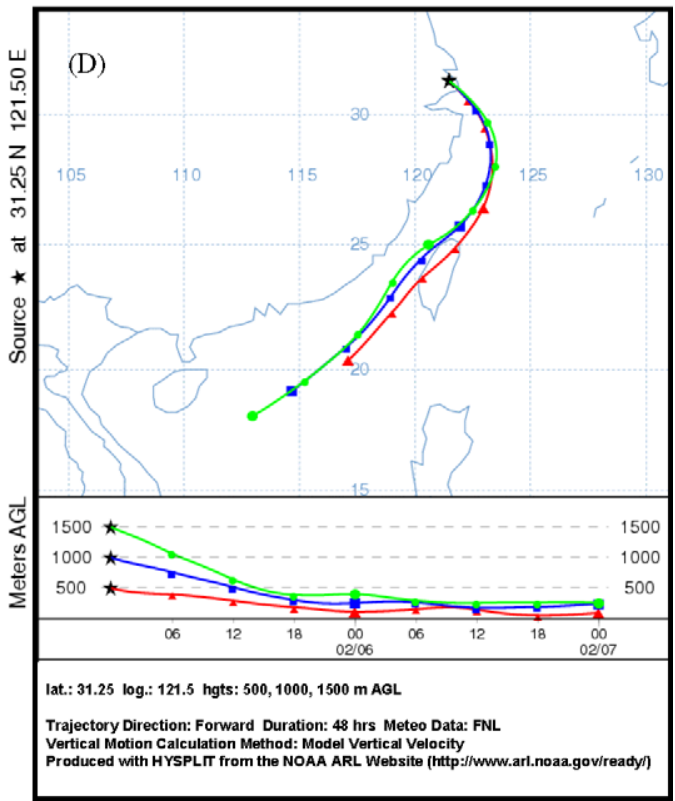

Fig. 2. Backward (from Taipei, Taiwan) and forward (from Shanghai, China) air mass trajectory analysis for 2 days: November 29 (November 28 for forward analysis) 2003 (upper panel) and February 6 (February 5 for forward analysis) 2004 (lower panel); both were carried out by using the HYSPLIT Model, NOAA. 
of anthropogenic aerosols in the northeast monsoon seasons, and the effective removal by frequent rain in the summer monsoon season.

\subsection{Characteristics of $\mathrm{Pb}$ isotope ratios for identifying Pb sources in Taipei aerosols}

Results of $\mathrm{Pb}$ isotope ratios for Taipei ambient aerosols are summarized in Table 3. Fig. 3 displays the scatter plots of ${ }^{208} \mathrm{~Pb} /{ }^{207} \mathrm{~Pb}$ ( $x$-axis) versus ${ }^{206} \mathrm{~Pb} /{ }^{207} \mathrm{~Pb}$ ( $y$-axis) for $\mathrm{PM}_{10}$ and $\mathrm{PM}_{2.5}$ aerosols. Overall, ${ }^{208} \mathrm{~Pb} /{ }^{207} \mathrm{~Pb}$ and ${ }^{206} \mathrm{~Pb} /{ }^{207} \mathrm{~Pb}$ isotope ratios of all samples fell within a moderate range from 2.35 to 2.45 and from 1.12 to 1.17 (with two exceptions), respectively. There are almost no differences between $\mathrm{PM}_{10}$ and $\mathrm{PM}_{2.5}$ aerosols (Fig. 3); it is not surprising as fine mode aerosol particles dominate $\mathrm{Pb}$ partitions (Fig. 1), resulting in $\mathrm{Pb}$ isotope ratios in $\mathrm{PM}_{10}$ aerosols resembling those in $\mathrm{PM}_{2.5}$ aerosols. Note that in Fig. $3 \mathrm{~Pb}$ isotope ratios for four months (seasons) seem to be differentiable although they look like clustering together; seasonal variations will hence be considered below. Also shown in Fig. 3, there are two characteristic isotope ratios in Chinese and Australian aerosol particles identified by Bollhofer and Rosman (2001). According to reports by Council for Economic Planning and Development, Taiwan, the main import country of lead ores for Taiwan demands has changed from Australia to mainland China in this recent decade. To evaluate the possible sources, represented areas of airborne $\mathrm{Pb}$ isotope ratios from the two countries were therefore indicated in the plots. Overall, most of our isotopic data certainly fell within the two areas. Nonetheless, we cannot make a definite conclusion regarding the relative contributions until robust evidence can be provided.

As depicted in Figs. 4 and $5,{ }^{206} \mathrm{~Pb} /{ }^{207} \mathrm{~Pb}$ and ${ }^{208} \mathrm{~Pb} /{ }^{207} \mathrm{~Pb}$ ratios vary evidently among 4 months (also representing four seasons) similarly for $\mathrm{PM}_{10}$ (Fig. 4) and $\mathrm{PM}_{2.5}$ (Fig. 5) samples. The seasonality is obvious, showing an increasing trend from summer to fall to winter to spring. Also shown in these plots are the ratios of tunnel particles collected from two principal traffic tunnels in downtown Taipei, which are assumed to represent the local vehicle emission source. As illustrated in Figs. 4 and 5, the ${ }^{206} \mathrm{~Pb} /{ }^{207} \mathrm{~Pb}$ ratios (1.131) of tunnel particles are very close to the summer mean ratio (1.132) of ambient aerosols, while the ${ }^{208} \mathrm{~Pb} /{ }^{207} \mathrm{~Pb}$ ratio (2.405) of tunnel particles are moderately higher than the summer ratios. The summer is a very clean season,

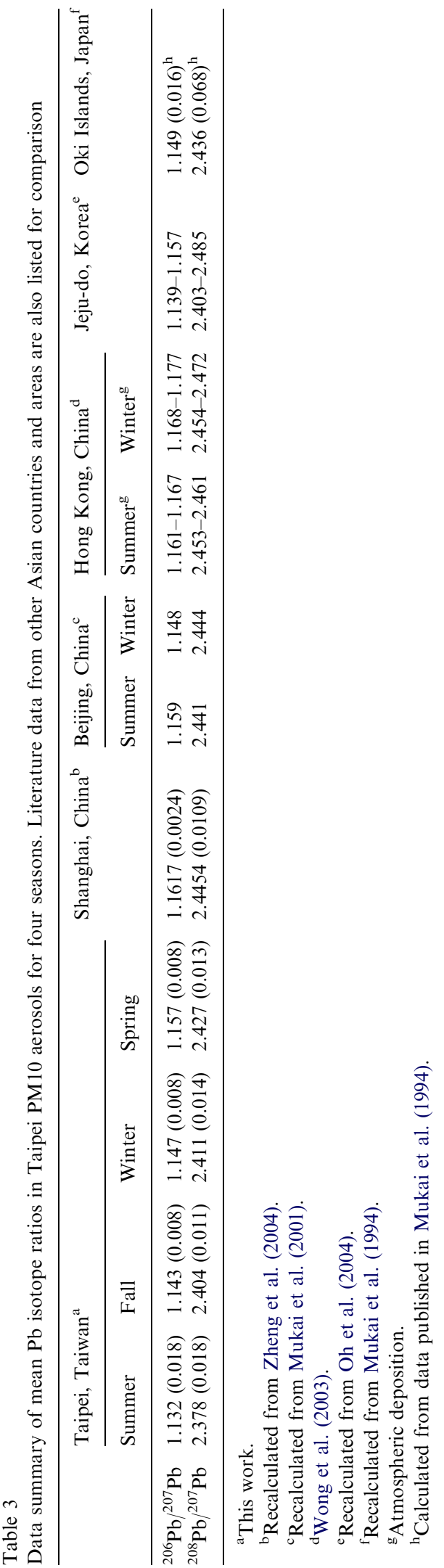



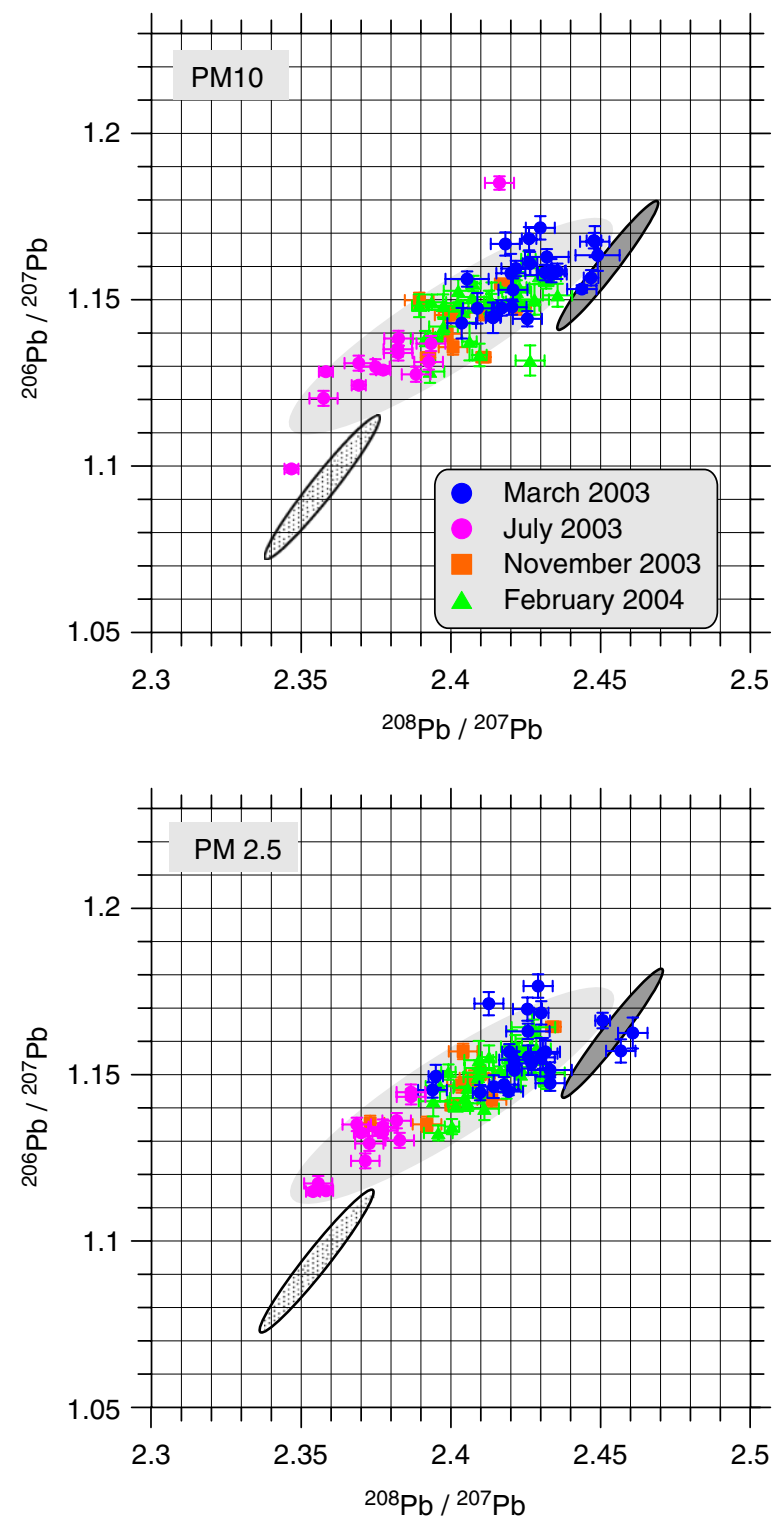

Fig. 3. Scatter plots of ${ }^{206} \mathrm{~Pb} /{ }^{207} \mathrm{~Pb}$ vs. ${ }^{208} \mathrm{~Pb} /{ }^{207} \mathrm{~Pb}$ for $\mathrm{PM}_{10}$ (upper panel) and $\mathrm{PM}_{2.5}$ (lower panel) aerosol particles taken from 4 months (seasons) in Taipei. A light-grayed ellipse area represents data points for a general pattern of ${ }^{206} \mathrm{~Pb} /{ }^{207} \mathrm{~Pb}$ vs. ${ }^{208} \mathrm{~Pb} /{ }^{207} \mathrm{~Pb}$. The dark-grayed area indicates the characteristic isotope ratios for the Chinese aerosols and the dotted area for the Australian aerosols; refer to Bollhofer and Rosman (2001) for details. The reason of showing the data area for China and Australia is that they are the major exporting countries of $\mathrm{Pb}$ ores to Taiwan.

suggestive to be conclusively affected by local pollution emissions, at least without significant long-range transported pollutants from mainland China (Wang, 2005). Therefore, this indicates that apart from vehicle emissions there are additional $\mathrm{Pb}$

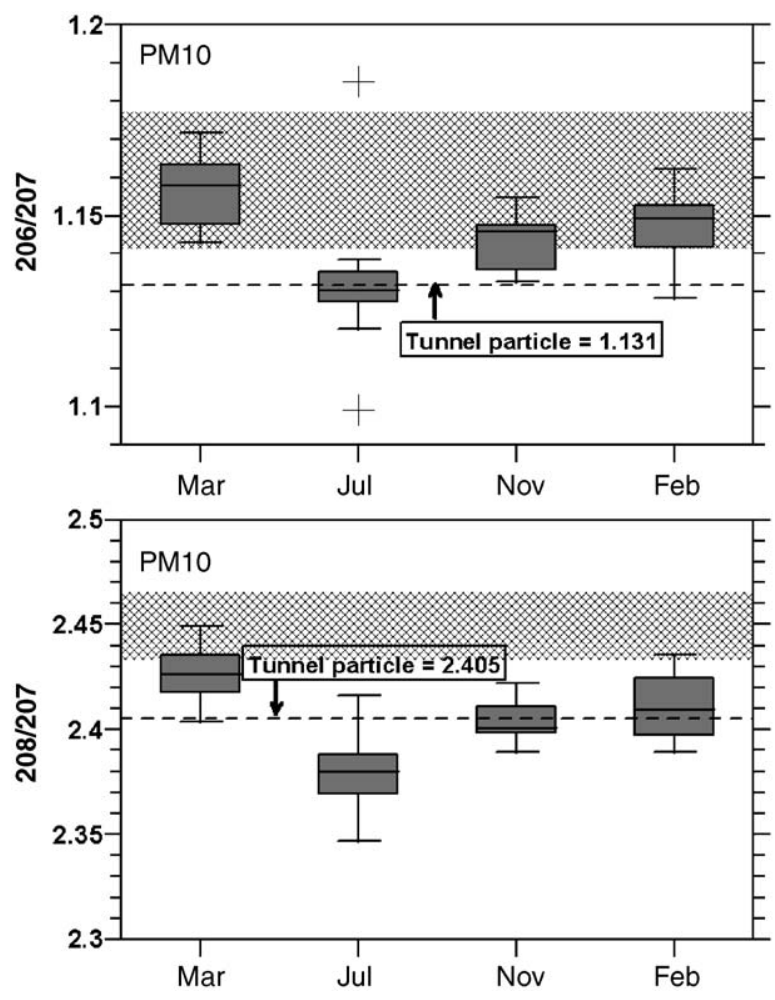

Fig. 4. Seasonal (individual month representing each season) variations in ${ }^{206} \mathrm{~Pb} /{ }^{207} \mathrm{~Pb}$ (upper panel) and ${ }^{208} \mathrm{~Pb} /{ }^{207} \mathrm{~Pb}$ (lower panel) isotope ratios in Taipei $\mathrm{PM}_{10}$ aerosol particles. Also indicated by a dashed line in the plots is the average value of tunnel particles. Additionally, the range of $\mathrm{Pb}$ isotope ratios in atmospheric particles from China reported by Bollhofer and Rosman (2001) is marked by a cross square area.

sources such as incineration, metalliferous industry and coal combustion of fire power plants in summer (Hsu et al., 2005); the isotopic signatures of other local sources need to be determined for identifying more sources. In view of other seasons when the northeastern monsoon prevails approximately starting in late September, both ${ }^{206} \mathrm{~Pb} /{ }^{207} \mathrm{~Pb}$ and ${ }^{208} \mathrm{~Pb} /{ }^{207} \mathrm{~Pb}$ ratios progressively increase to the maximal peak in spring (Figs. 4 and 5), corresponding to the increased impact of long-range transport at that time. Thereby, the impact can reach a maximum in spring.

Chen et al. (2005) pointed out that lead air pollution continued over Shanghai after the phaseout of leaded gasoline in 1995. On the basis of nearly 10-year long-term measurements, the seasonal pattern always showed a winter maximum. At present, the average winter concentrations are still as high as $500 \mathrm{ng} \mathrm{m}^{-3}$ although they have declined substantially from several $\mu \mathrm{g} \mathrm{m}^{-3}$. According to the 

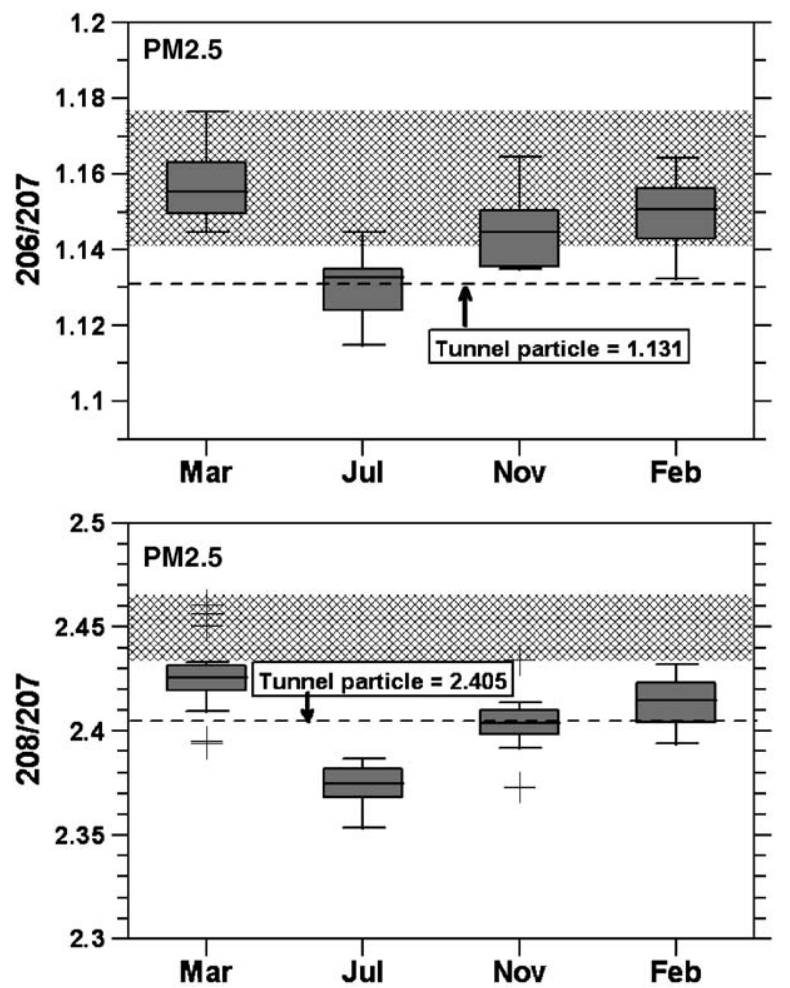

Fig. 5. As in Fig. 4, but for $\mathrm{PM}_{2.5}$ aerosol particles.

$\mathrm{Pb}$ isotopic compositions of total suspended particles (TSP) in air, Chen et al. (2005) suggested that stationary pollution emission was always a dominant source in Shanghai and that the primary components was believed to be contributed by vast combustion of lead-containing coal utilized mainly by industrial activities recently. These authors further assessed the contribution from leaded gasoline being only $27.5 \%$. Likewise, Zheng et al. (2004) analyzed $\mathrm{Pb}$ isotope ratios in Shanghai $\mathrm{PM}_{10}$ aerosols, and reported characteristic $\mathrm{Pb}$ isotope ratios in $\mathrm{PM}_{10}$ aerosols to be $0.8608 \pm 0.0018$ for ${ }^{207} \mathrm{~Pb} /{ }^{206} \mathrm{~Pb}$ ratios and $2.105 \pm 0.005$ for ${ }^{208} \mathrm{~Pb} /{ }^{206} \mathrm{~Pb}$ ratios, that can be converted to 1.162 for ${ }^{206} \mathrm{~Pb} /{ }^{207} \mathrm{~Pb}$ and 2.445 for ${ }^{208} \mathrm{~Pb} /{ }^{207} \mathrm{~Pb}$. They evaluated the contribution of $\mathrm{Pb}$ from vehicle exhausts to be around $20 \%$, somewhat lower than the estimate $(27 \%)$ by Chen et al. (2005). Zheng et al. (2004) demonstrated that the major emission sources of atmospheric $\mathrm{Pb}$ included metallurgic dust, coal combustion and cement. Based on single aerosol particle analyses using a nuclear microprobe, Wang et al. (2000) suggested the cement industry, coal combustion, oil combustion, metallurgic dust and automobile exhaust responsible for lead pollution in Shanghai air.
For comparison, isotopic data for atmospheric $\mathrm{Pb}$ from East Asian countries and areas are also summarized in Table 3. Comparing our $\mathrm{Pb}$ isotope ratios with those measured in China, the spring ${ }^{206} \mathrm{~Pb} /{ }^{207} \mathrm{~Pb}$ ratio $(1.157 \pm 0.008)$ is rather comparable to that (1.162) measured in Shanghai $\mathrm{PM}_{10}$ aerosols as mentioned above (Zheng et al., 2004, Fig. 6). Furthermore, Chen et al. (2005) observed that the ${ }^{206} \mathrm{~Pb} /{ }^{207} \mathrm{~Pb}$ ratio in Shanghai aerosols has switched from $1.147 \pm 0.002$ before 1995 to the current characteristic value of $1.162 \pm 0.002$, responding to the phase-out of leaded gasoline in Shanghai in 1995. Compared with the ratios of 1.141-1.177 for ${ }^{206} \mathrm{~Pb} /{ }^{207} \mathrm{~Pb}$ and $2.435-2.465$ for ${ }^{208} \mathrm{~Pb} /{ }^{207} \mathrm{~Pb}$ measured in China (Bollhofer and Rosman, 2001), most data of our northeastern monsoon samples fall within their ranges although some data points fall at the lower end of characteristic ratio ranges, as indicated by the dotted area in Fig. 3. This illustrates that the springtime values are closer to those of China aerosols (Figs. 4 and 5). The present result of similarity in $\mathrm{Pb}$ isotopes, together with statistical results of long-term airmass trajectories given by Wang (2005), reveals the domination of long-range transport of Chinese $\mathrm{Pb}$ pollution principally from the Yangtze Delta in spring.

Now a question may be raised as to why $\mathrm{Pb}$ concentrations have not reached a spring maximum (but showed a spring minimum, Fig. 2) to correspond to the ${ }^{206} \mathrm{~Pb} /{ }^{207} \mathrm{~Pb}$ and ${ }^{208} \mathrm{~Pb} /{ }^{207} \mathrm{~Pb}$ maxima in spring (Fig. 4). Along with high emissions from coal combustion in winter, two other processes may be responsible for the seasonality. First, frequent rain associated with frontal systems often occurring around the offshore area of northern Taiwan in the spring (on average, 15 rainy days per month or more in spring) can remove a majority of airborne $\mathrm{Pb}$ particles and/or $\mathrm{Pb}$-bounded aerosol particles regardless of local and long-range transported origins. Moreover, another important process is the preferential deposition of coarse particles due to gravitational settling like dust aerosol, which seems to be a crucial host particle of atmospheric $\mathrm{Pb}$ from the Chinese continental pollution outbreak (Hsu et al., 2005).

\subsection{Estimating the relative contribution from long- range transport}

In summer air compositions of Taiwan are seldom affected by long-range transport from 
China. Therefore the summertime air can represent the local background air (Wang, 2005). Alternatively, the summertime aerosol $\mathrm{Pb}$ isotope ratios can be regarded as a characteristic ratio of representing local aerosols of anthropogenic origin. It thus allowed the probable assessment of the relative contribution for airborne $\mathrm{Pb}$ through long-range transport in respective seasons other than summer. We adopted a two end-member mixing model to compute the contribution using the following equation (Flament et al., 2002):

$R_{\mathrm{obs}}=R_{\mathrm{lp}} X_{\mathrm{lp}}+R_{\mathrm{lrt}}\left(1-\mathrm{X}_{\mathrm{lp}}\right)$,

where $R_{\mathrm{obs}}$ is the observed isotope ratio in the northeast monsoon season (i.e., fall, winter and spring) other than summer, $R_{\mathrm{lp}}$ is the characteristic ratio of local aerosols represented by the summertime value, $R_{1 \mathrm{rt}}$ is the characteristic ratio of longrange transported $\mathrm{Pb}$-bound aerosols represented by the mean value of Shanghai aerosols, $X_{\mathrm{lp}}$ is the relative contribution through local pollution, and $\left(1-X_{\text {lp }}\right)$ is the relative contribution through longrange transport. Then we separately calculated the contributions by using the ${ }^{206} \mathrm{~Pb} /{ }^{207} \mathrm{~Pb}$ and ${ }^{208} \mathrm{~Pb} /{ }^{207} \mathrm{~Pb}$ isotopic data. All the parameters used in the calculations are given in Table 4. Here the representative values of ${ }^{206} \mathrm{~Pb} /{ }^{207} \mathrm{~Pb}$ and ${ }^{208} \mathrm{~Pb} /{ }^{207} \mathrm{~Pb}$ isotope ratios for the local $\mathrm{Pb}$ pollution are the summertime data (i.e., 1.132 and 2.378, respectively, Tables 3 and 4) while for the long-range transport of aerosol $\mathrm{Pb}$ are the Shanghai $\mathrm{PM}_{10}$ data (i.e., 1.1617 and 2.4454, Table 4) that were calculated from isotopic data reported by Zheng et al. (2004). The result is that the seasonal contributions of longrange transport of airborne $\mathrm{Pb}$ vary from $38 \%$ $(39 \%)$ in fall to $52 \%(49 \%)$ in winter to $84 \%(73 \%)$ in spring when using the ${ }^{206} \mathrm{~Pb} /{ }^{207} \mathrm{~Pb}\left({ }^{208} \mathrm{~Pb} /{ }^{207} \mathrm{~Pb}\right)$ isotopic data. The relative contributions based on the ${ }^{206} \mathrm{~Pb} /{ }^{207} \mathrm{~Pb}$ or ${ }^{208} \mathrm{~Pb} /{ }^{207} \mathrm{~Pb}$ isotopic data seem to be quite consistent, implying that the impact of long-range transport of air pollutants from developing China, especially the Yangtze Delta, is very substantial.

The estimated contributions of long-range transport ranging from $38 \%$ to $84 \%$ in the northeastern monsoon is very consistent with our previous study that $\mathrm{Cd} / \mathrm{Pb}$ ratios in Taipei aerosols were low (0.018) in the Asian dust episodes, reflecting longrange transport, whereas high (0.030) in summer, reflecting local pollution (Hsu, et al., 2005). In the northeast monsoon other than Asian dust periods there is a moderate $\mathrm{Cd} / \mathrm{Pb}$ ratio of 0.024 . Likewise, by employing a two end-member mixing model, it thus allows us to make a rough estimation of the long-range transport of anthropogenic metals in the monsoon, the value being $50 \%$ for $\mathrm{Pb}$. In addition, the estimations of long-range transport contributions for airborne $\mathrm{Pb}$ in the northeast monsoon in Taipei are somewhat consistent with those for various pollutant species such as $\mathrm{PM}_{10}$ aerosol and CO in northern Taiwan (Lin et al., 2005).

\section{Summary}

This is the first report dealing with atmospheric $\mathrm{Pb}$ isotopic signatures to evaluate the impact of long-range transport from China. A 2-year longterm measurement result of atmospheric $\mathrm{Pb}$ shows an evident seasonality of high winter and low summer/spring concentrations, demonstrating that long-range southward transport of air pollutants from the China continental outflows greatly enhanced atmospheric concentrations of anthropogenic metals such as $\mathrm{Pb}$ in winter. Differentiating anthropogenic $\mathrm{Pb}$ from various sources can be achieved by $\mathrm{Pb}$ isotopic signatures. Low ${ }^{206} \mathrm{~Pb} /{ }^{207} \mathrm{~Pb}$ and ${ }^{208} \mathrm{~Pb} /{ }^{207} \mathrm{~Pb}$ ratios were observed in summer

Table 4

Estimated relative contributions (\%) from local pollution and long-range transport for airborne $\mathrm{Pb}$ in the northeast monsoon season (including spring, fall and winter) in Taipei

\begin{tabular}{lllll}
\hline & \multicolumn{2}{l}{ Long-range transport } & & \multicolumn{2}{l}{ Local pollution } \\
\cline { 2 - 3 } & ${ }^{206} \mathrm{~Pb} /{ }^{207} \mathrm{~Pb}(1.1617)$ & & ${ }^{206} \mathrm{~Pb} /{ }^{207} \mathrm{~Pb}(1.132)$ & 16 \\
\hline Spring & 84 & 73 & 62 & 27 \\
Fall & 38 & 39 & 48 & 61 \\
Winter & 52 & 49 & $\left.{ }^{208} \mathrm{~Pb} / 2.4454\right)$ & 51 \\
\hline
\end{tabular}

Also given in the parentheses are the characteristic values of ${ }^{206} \mathrm{~Pb} /{ }^{207} \mathrm{~Pb}$ or ${ }^{208} \mathrm{~Pb} /{ }^{207} \mathrm{~Pb}$ isotope ratios used for representing the two sources to calculate the contribution. Refer to the text for details. 
aerosols, followed by an increase from fall to winter and a maximum in spring; the isotope ratios gradually become similar to those detected in Shanghai (Yangtze Delta), China. Together with backward and forward air-mass trajectory analysis, it reveals an increased impact of long-range transport with varying northeast monsoon seasons. A two end-member mixing model was adopted to assess the relative contributions of long-range transport of airborne $\mathrm{Pb}$. Results show an increased contribution from nearly $40 \%$ in fall to $85 \%$ in spring, certainly demonstrating the substantial influence of the Chinese pollution outbreak on Taiwan local air quality.

Because of the present fast development of industry in China it can be expected that the air pollution in China will become more severe in the future years. Consequently, it can further be predicted that the impact of long-range transport of air pollutants will be continued. Obviously, this needs to be taken care of when implementing the air quality management for Taiwanese governments.

\section{Acknowledgments}

We thank Mr. T.K. Chen and Mr. C.H. Liu for their help with sampling. Thanks are also extended to Profs. C.A. Huh, C.H. Wang, F.K. Shiah and S.J. Kao for their helpful comments and suggestions. Special thanks go to the Climate Monitoring and Diagnostics Laboratory of the National Oceanic and Administration (USA) for providing air mass back trajectories. This work was supported by the theme research project of Academia Sinica (Project number: 33, 2002) and Environmental Protection Administration grants EPA-91-FA1103-A062 to S. C. L.

\section{References}

Becker, J.S., Dietze, H.J., 2000. Precise and accurate isotope ratio measurements by ICP-MS. Fresenius Journal of Analytical Chemistry 368, 23-30.

Bollhofer, A., Rosman, K.J.R., 2001. Isotopic source signatures for atmospheric lead: the Northern Hemisphere. Geochimica et Cosmochimica Acta 65, 1727-1740.

Chen, J.M., Tan, M.G., Li, Y.L., Zhang, Y.M., Lu, W.W., Tong, Y.P., Zhang, G.L., Li, Y., 2005. A lead isotope record of Shanghai atmospheric lead emissions in total suspended particles during the period of phasing out of leaded gasoline. Atmospheric Environment 39, 1245-1253.

Dan, M., Zhuang, G.S., Li, X.X., Tao, H.R., Zhuang, Y.H., 2004. The characteristics of carbonaceous species and their sources in PM2.5 in Beijing. Atmospheric Environment 38, 3443-3452.

Fang, M., Zheng, M., Wang, F., Chim, K.S., Kot, S.C., 1999. The long-range transport of aerosols from northern China to Hong Kong-A multi-technique study. Atmospheric Environment 33, 1803-1817.

Flament, P., Bertho, M.L., Deboudt, K., Veron, A., Puskaric, E., 2002. European isotopic signatures for lead in atmospheric aerosols: a source apportionment based upon $\mathrm{Pb}-206 / \mathrm{Pb}-207$ ratios. Science of the Total Environment 296, 35-57.

Ho, K.F., Lee, S.C., Chan, C.K., Yu, J.C., Chow, J.C., Yao, X.H., 2003. Characterization of chemical species in PM2.5 and PM10 aerosols in Hong Kong. Atmospheric Environment 37, 31-39.

Hsu, S.C., Liu, S.C., Lin, C.Y., Hsu, R.T., Huang, Y.T., Chen, Y.W., 2004. Metal compositions and characterizations of $\mathrm{PM}_{10}$ and $\mathrm{PM}_{2.5}$ aerosols in Taipei during the springtime, 2002. Terrestrial, Atmospheric and Oceanic Sciences 15, 925-948.

Hsu, S.C., Liu, S.C., Jeng, W.L., Lin, F.J., Huang, Y.T., Lung, S.C.C., Liu, T.H., Tu, J.Y., 2005. Variations of $\mathrm{Cd} / \mathrm{Pb}$ and $\mathrm{Zn} / \mathrm{Pb}$ ratios in Taipei aerosols reflecting long-range transport or local pollution emissions. Science of the Total Environment 347, 111-121.

Kim, K.H., Song, D.W., 1997. The concentrations of lead in urban and nonurban atmospheres of Won Ju City, Korea. Water, Air Soil Pollution 98, 255-273.

Lin, C.Y., Liu, S.C., Chou, C.C.K., Huang, S.J., Liu, C.M., Kuo, C.H., Young, C.Y., 2005. Long-range transport of aerosols and their impact on the air quality of Taiwan. Atmospheric Environment 39, 6066-6076.

Lin, F.J., Hsu, S.C., Jeng, W.L., 2000. Lead in the southern East China Sea. Marine Environmental Research 49, 329-342.

Mao, I.F., Chen, M.L., 1996. Airborne lead pollution in metropolitan Taipei (Republic of China). Water, Air and Soil Pollution 91, 375-382.

Marcantonio, F., Zimmerman, A., Xu, Y.F., Canuel, E., 2002. A $\mathrm{Pb}$ isotope record of mid-Atlantic US atmospheric $\mathrm{Pb}$ emissions in Chesapeake Bay sediments. Marine Chemistry 77, 123-132.

Mishra, V.K., Kim, K.H., Kang, C.H., Choi, K.C., 2004. Wintertime sources and distribution of airborne lead in Korea. Atmospheric Environment 38, 2653-2664.

Monna, F., Lancelot, J., Croudace, I.W., Cundy, A.B., Lewis, J.T., 1997. $\mathrm{Pb}$ isotopic composition of airborne particulate material from France and the southern United Kingdom: Implications for $\mathrm{Pb}$ pollution sources in urban areas. Environmental Science \& Technology 31, 2277-2286.

Monna, F., Loizeau, J.L., Thomas, B., Gueguen, C., Favarger, P.Y., Losno, R., Dominik, J., 2000. Noise identification and sampling frequency determination for precise $\mathrm{Pb}$ isotopic measurements by quadrupole-based inductively coupled plasma mass spectrometry. Analusis 28, 750-757.

Mukai, H., Tanaka, A., Fujii, T., Nakao, M., 1994. Lead isotope ratios of airborne particulate matter as tracers of long-range transport of air pollutants around Japan. Journal of Geophysical Research 99, 3717-3726.

Mukai, H., Tanaka, A., Fujii, T., Zeng, Y.Q., Hong, Y.T., Tang, J., Guo, S., Xue, H.S., Sun, Z.L., Zhou, J.T., Xue, D.M., Zhao, J., Zhai, G.H., Gu, J.L., Zhai, P.Y., 2001. Regional characteristics of sulfur and lead isotope ratios in the 
atmosphere at several Chinese urban sites. Environmental Science \& Technology 35, 1064-1071.

Nriagu, J.O., 1989. The history of leaded gasoline. In: Vernet, J.P. (Ed.), Heavy Metals in the Environment. Page Bros, pp. 361-366.

Nriagu, J.O., 1996. A history of global metal pollution. Science 272, 223-224.

Oh, Y.K., Ryu, S.P., Kim, H.C., Kawamura, H., Tennichi, Y., Matsuoka, N., Maeda, Y., 2004. Source identification of $\mathrm{Pb}$ in aerosols at Jeju-do, Korea by using Pb-207/Pb-206 and Pb208/Pb-206. Journal of Radioanalytical and Nuclear Chemistry $260,279-282$.

Patterson, C.C., Settle, D.M., 1987. Review of data on eolian fluxes of industrial and natural lead to the land and seas in remote regions on a global scale. Marine Chemistry 22, $137-162$.

Planchon, F.A.M., van de Velde, K., Rosman, K.J.R., Wolff, E.W., Ferrari, C.P., Boutron, C.F., 2003. One hundred fiftyyear record of lead isotopes in Antarctic snow from Coats Land. Geochimica et Cosmochimica Acta 67, 693-708.

Renberg, I., Wik-Persson, M., Emteryd, O., 1994. Pre-industrial atmospheric lead contamination detected in Swedish lake sediments. Nature 368, 323-326.

Rosman, K.J.R., Ly, C., Steinnes, E., 1998. Spatial and temporal variation in isotopic composition of atmospheric lead in Norwegian moss. Environmental Science \& Technology 32, 2542-2546.

Shen, G.T., Boyle, E.A., 1987. Lead in corals: reconstruction of historical industrial fluxes to the surface ocean. Earth and Planetary Science Letters 82, 289-304.

Shotyk, W., Weiss, D., Appleby, P.G., Cheburkin, A.K., Frei, R., Gloor, M., Kramers, J.D., Reese, S., Van der Knaap, W.O., 1998. History of atmospheric lead deposition since 12,370 C14 yr BP from a peat bog, Jura Mountains, Switzerland. Science 281, 1635-1640.
Sturges, W.T., Barrie, L.A., 1987. Lead 206/207 isotope ratios in the atmosphere of North America as tracers of US and Canadian emission. Nature 239, 144-146.

Sun, Y.L., Zhuang, G.S., Ying, W., Han, L.H., Guo, J.H., Mo, D., Zhang, W.J., Wang, Z.F., Hao, Z.P., 2004. The air-borne particulate pollution in Beijing - concentration, composition, distribution and sources. Atmospheric Environment 38, 5991-6004.

Var, F., Narita, Y., Tanaka, S., 2000. The concentration, trend and seasonal variation of metals in the atmosphere in 16 Japanese cities shown by the results of National Air Surveillance Network (NASN) from 1974 to 1996. Atmospheric Environment 34, 2755-2770.

Wang, K.Y., 2005. A 9-year climatology of airstreams in East Asia and implications for the transport of pollutants and downstream impacts. Journal of Geophysical ResearchAtmospheres 110 Art. No. D07306.

Wang, J., Guo, P., Li, X., Zhu, J., Reinert, T., Heitmann, J., Spemann, D., Vogt, J., Flagmeyer, R.H., Butz, T., 2000. Source identification of lead pollution in the atmosphere of Shanghai City by analyzing single aerosol particles (SAP). Environmental Science \& Technology 34, 1900-1905.

Wong, C.S.C., Li, X.D., Zhang, G., Qi, S.H., Peng, X.Z., 2003. Atmospheric deposition of heavy metals in the Pearl River Delta, China. Atmospheric Environment 37, 767-776.

Zhang, Z.Q., Friedlander, S.K., 2000. A comparative study of chemical databases for fine particle Chinese aerosols. Environmental Science \& Technology 34, 4687-4694.

Zheng, J., Tan, M.G., Shibata, Y., Tanaka, A., Li, Y., Zhang, G.L., Zhang, Y.M., Shan, Z., 2004. Characteristics of lead isotope ratios and elemental concentrations in PM10 fraction of airborne particulate matter in Shanghai after the phase-out of leaded gasoline. Atmospheric Environment 38, 1191-1200. 